\title{
Article
}

\section{Real-Time PCR Confirms Infection with Lagovirus europaeus}

\author{
Dominika Bębnowska (D), Rafał Hrynkiewicz (D) and Paulina Niedźwiedzka-Rystwej *(D) \\ Institute of Biology, University of Szczecin, Felczaka 3c, 71-412 Szczecin, Poland; \\ dominika.bebnowska@usz.edu.pl (D.B.); rafal.hrynkiewicz@usz.edu.pl (R.H.) \\ * Correspondence: paulina.niedzwiedzka-rystwej@usz.edu.pl
}

Featured Application: Our experience with real-time PCR, together with several different studies in this field show that this is a very useful method for rapid, specific and effective virus detection.

\begin{abstract}
Lagovirus europaeus GI.1/GI.2 is an etiological agent causing the highly dangerous rabbit hemorrhagic disease (RHD). Molecular research is the basic tool today that can help solve epidemic problems related to the expansion of pathogens in the world. By using the real-time polymerase chain reaction technique (PCR), we detected three different strains of Lagovirus europaeus/GI.1, which is an RNA virus infecting mainly rabbits. The results showed that the method used was fast, very specific, and effective.
\end{abstract}

Keywords: rabbit hemorrhagic disease; real-time PCR; Lagovirus europaeus; RHDV- rabbit haemorrhagic disease virus

\section{Introduction}

Lagovirus (L.) europaeus GI.1 and GI.2 is an etiological agent that causes a severe and

Citation: Bẹbnowska, D.;

Hrynkiewicz, R.;

Niedźwiedzka-Rystwej, P. Real-Time PCR Confirms Infection with

Lagovirus europaeus. Appl. Sci. 2021,

11, 656. https://doi.org/10.3390/

app11020656

Received: 12 December 2020

Accepted: 6 January 2021

Published: 11 January 2021

Publisher's Note: MDPI stays neutral with regard to jurisdictional clai$\mathrm{ms}$ in published maps and institutional affiliations.

Copyright: $\odot 2021$ by the authors. Licensee MDPI, Basel, Switzerland. This article is an open access article distributed under the terms and conditions of the Creative Commons Attribution (CC BY) license (https:// creativecommons.org/licenses/by/ $4.0 /)$. highly lethal disease-RHD (rabbit hemorrhagic disease) [1]. The problems posed by the spread of this virus around the globe concern not only economic considerations, in the case of countries whose economies are based on the rabbit industry, but also the negative impact of the virus on the environment [2,3]. In addition, the interest in L. europaeus is influenced by the fact that it is a model in the study of the variability of a whole range of RNA viruses, which are common pathogens in animals. The basic element necessary to start fighting any pathogen is its effective diagnosis. Nowadays, the most respected molecular methods are definitely leading the way. One of the most commonly used methods is the real-time polymerase chain reaction technique-real-time PCR [4]. This method is one of many modifications of the classical PCR reaction and is characterized by the use of a fluorescent dye that allows the analysis of product growth by following the quantitative measurement of the excited fluorescence [4]. In this method, a logarithmic increase in the level of fluorescence is considered a positive result, which determines the increase in the product [4]. Thanks to this method, it is possible to detect small amounts of viral particles, which would be unattainable in the case of classical PCR. An additional advantage is that the method enables both quantitative and qualitative analysis of the material, which makes it possible to significantly shorten and simplify the procedure [4].

L. europaeus is a virus belonging to the genus Lagovirus within the family Caliciviridae, which is formed by non-enveloped ssRNA (+) viruses [5]. Within the GI genogroup, the GI.1 and GI.2 genotypes are distinguished, with four variants (a-d) observed in GI.1 [6]. The first mentions of the L. europaeus GI.1 virus appeared in 1984 in China [7]. Due to the fact that the virus was characterized by a high level of mortality and a significant pace of expansion, its range became global in a relatively short time [1]. In 1997, the L. europaeus GI.1a virus was identified in Italy. Its antigenic features were significantly different from the previously isolated strains, and on this basis, it was considered the first antigenic 
variant of rabbit hemorrhagic disease virus [8]. The presence of this pathogen was then confirmed in many places around the world, where it usually tended to displace strains belonging to other genogroups from the environment [9]. The appearance of the new virus L. europaeus GI.2 was first recorded in France in 2010, among both individuals vaccinated and not vaccinated against L. europaeus GI.1, showing symptoms typical of RHD [10]. In a short time, this factor was recognized in many countries, where it usually tended to displace strains belonging to the GI.1 genogroup from the environment [2].

A single virus particle is a non-enveloped structure of $35-40 \mathrm{~nm}$. Viral ssRNA (+) is presented as two overlapping reading frames (ORF), and its size is approximately $7.5 \mathrm{~kb}$ [1]. The virion also shows the presence of $2.2 \mathrm{~kb}$ subgenomic RNA [1]. The ORF1 frame is located at the $5^{\prime}$ end and encodes a $257 \mathrm{kDa}$ polyprotein, from which the proteins VP60, P16, P23, and P29 are formed as a result of the action of proteases. On the other hand, the ORF2 frame is at the $3^{\prime}$ end and encodes the VP10 protein [1]. The viral capsid has 90 dimers of the VP60 protein, forming 32 wells. This protein consists of two domains called S and P. Additionally, the P domain is divided into the P1 subdomain and the P2 subdomain, which forms the most advanced part of the capsid [1]. Moreover, six regions (A-F) have been described that show exceptionally strong genetic variation among the isolated strains [11]. It was described that the F region influences the ability of the strains to hemagglutinate, as well as the $\mathrm{C}$ and $\mathrm{E}$ regions, which are assigned the highest degree of genetic variability. This is confirmed by the fact that host antibodies react with epitopes located in the P2 subdomain, and therefore evolutionary genetic diversity results in the emergence of strains with different antigenicity [12].

\section{Real-Time PCR in Lagovirus europaeus GI.1 and GI.2 Studies}

Real-time PCR is a routine diagnostic tool in L. europaeus GI.1 and GI.2 infection [4]. Le Gall et al. [13] were one of the first research teams to use real-time PCR in the diagnosis of L. europaeus GI.1. The analysis of the obtained results revealed $100 \%$ sensitivity of the method, and the possibility of detecting 10 copies of the virus per well and linearity in the range of $10^{1}$ to $10^{10}$ copies [13]. The usefulness of real-time PCR was noticed by Nyström et al. [14], who used this method to analyze the differentiation of HBGA (histo-blood group antigen binding capacity) among strains showing different pathogenicity to confirm the presence of viral RNA in the liver of experimentally infected rabbits. The potential of real-time PCR has also been verified by Niedźwiedzka-Rystwej et al. [4], who in their studies determined the specificity of virus detection in the livers of rabbits, experimentally infected with L. europaeus GI.1 17 strains, showing different biological characteristics such as antigenicity, hemagglutination capacity, and induced mortality. It was reported that realtime PCR was also used by Liu et al. [15], who analyzed the distribution of the virus (strain XA/2010 L. europaeus GI.1) at various sites in infected rabbits. In this study, the liver, heart, trachea, spleen, kidneys, lungs, small intestine, and body fluids (urine, saliva, and intestinal contents) were subjected to the presence of viral RNA. Analysis of the results revealed that the most copies of the virus were in the spleen, while the smallest amounts were found in the small intestine. So far, it has been found that four different lagoviruses circulate in Australia, of which three are in the GI.1 group. Thus, there was a need to develop a test to detect all of these factors, which is why Hall et al. [16] described a highly specific real-time PCR. The method validation revealed that the developed tests allow for wide and effective detection of all lagoviruses circulating in Australia, and for determination of the number of viral copies in the gastrointestinal tract with high accuracy, thus confirming the high utility of real-time PCR in virological research [16].

The appearance of L. europaeus GI.2 virus in 2010 was associated with the need to develop a rapid and effective diagnostic method. Identification of this factor has proved to be a key tool in limiting the occurrence of epizootics. Thus, Duarte et al. [17] proposed using real-time PCR for this purpose, which allows detection of the presence of L. europaeus GI.2 strains in less than three hours. Analysis of the obtained results showed that only nine viral RNA molecules were detected, and the average viral load was $1.5 \times 10^{7}$ virus 
copies in $1 \mathrm{mg}$ of tissue [17]. The obtained results were also used for the phylogenetic analysis of L. europaeus GI.2. It was found that despite the detection of the virus in 2016, it had already circulated in the environment in 2013; however, its identification had not been possible without the use of molecular methods [18]. RHD epidemiological studies are an important point in monitoring the current situation. Calvete et al. [19] conducted a study using real-time PCR, which showed the presence of the virus in the found corpse of a Mediterranean vole (Microtus duodecimcostatus) and two shrews (Crocidura russula). Therefore, it has been shown that within L. europaeus GI.2 there may be passive transmission of the virus to non-Lagomorpha species [19].

In this work, we use the real-time PCR method in the qualitative diagnosis of Lagovirus europaeus GI.1 strain 237/04, Lagovirus europaeus GI.1a strain 72V/2003, and recombinant strain Hartmannsdorf. Reassessing the effectiveness of this method seems to be necessary in view of the increasing spectrum of RHD-inducing factors. In our research, we have confirmed that real-time PCR is a quick and effective diagnostic method for pathogens causing RHD.

\section{Materials and Methods}

\subsection{Experiment}

In the experiment, we used liver tissue from rabbits, which died as a result of infection under experimental conditions with strains 237/04 (isolated in Austria, year 2004; GeneBank Accession no. MN218435), 72V / 2003 (isolated in Hungary, year 2003; GeneBank Accession no. MN218434), and Hartmannsdorf (isolated in Germany, year 1996; GeneBank Accession no. EF558586) of L. europaeus GI.1. The experiment was conducted in order to perform several immunological tests to measure the immunological status of the infected animals, published in [20-22]. All studies were conducted with the approval of the Local Ethics Committee for Experiments on Animals in Poznań (license no. 1/2009).

\subsection{Isolation of Viral RNA}

The tissue obtained was made a homogenate in a ratio of 1:3 with PBS (Phosphate Buffered Saline), and then total RNA was isolated from the prepared material using the Total RNA mini kit (A\&A Biotechnology, Gdynia, Poland) according to the manufacturer's instructions. The RNA obtained in this way was stored at $-80^{\circ} \mathrm{C}$ and then used for reverse transcription reaction.

\subsection{Reverse Transcription (RT) Reaction-cDNA Synthesis}

The complementary nucleic acid (cDNA) strand was obtained by reverse transcription on an RNA virus matrix. The reaction was carried out using a Transcriptor First Strand cDNA Synthesis Kit (Roche, Basel, Switzerland) according to the protocol developed by the manufacturer.

\subsection{Real-Time PCR}

The qualitative real-time PCR reaction was carried out using the primers designed previously [23,24], namely F (5'-AAATAgTgggACTKCAACCAgTACCT-3') and R ( $3^{\prime}$ ggAgATRgggTTgTCRAYTgCAgAC-5'), as well as the Light Cycler FastStart DNA Master SYBR Green I kit (Roche, Basel, Switzerland). The following temperature-time profiles were used: pre-denaturation $-95^{\circ} \mathrm{C} / 10 \mathrm{~min}$., amplification $/ 10 \mathrm{~min}$. -40 cycles, denaturation $-95^{\circ} \mathrm{C} / 10 \mathrm{~min}$., annealing of primers $-64{ }^{\circ} \mathrm{C} / 10$ sec., elongation $-72{ }^{\circ} \mathrm{C} / 7 \mathrm{sec}$. Analysis of melting curves: denaturation $-95^{\circ} \mathrm{C} / 5$ sec., annealing of primers $-65^{\circ} \mathrm{C} / 15 \mathrm{sec}$, melting $-95^{\circ} \mathrm{C}$, and cooling $-40^{\circ} \mathrm{C} / 30 \mathrm{sec}$. No template control was performed. During incubation in the thermocycler, fluorescence changes were observed and the melting curve analyzed to determine the specificity of the reaction. 


\section{Results}

Exponential increase in fluorescence was considered to be a positive result of the qualitative real-time PCR reaction (Figure 1). Analysis of the data obtained, which is presented in Table 1, showed that the $\mathrm{Ct}$ value, determining the reaction cycle in which the fluorescence emitted during amplification enters the logarithmic growth phase, occurred in the 18-24 reaction cycle for strain $237 / 04$, the 17-19 cycle for strain $72 \mathrm{~V} / 2003$, and the 18-22 cycle for strain Hartmannsdorf. In addition, the specificity of the analyzed products was confirmed by assessing the melting curves of the product (Figures 2 and 3). Analysis of the obtained values for the melting temperature $(\mathrm{Tm})$ for all the strains showed that these results are similar because their divergence fluctuates in the range of $\mathrm{Tm}=87.32-87.72{ }^{\circ} \mathrm{C}$. Similar Tm values in all samples exclude the possibility of a false result due to the formation of non-specific reaction products. Figure 4 shows the percentage distribution of the $\mathrm{Ct}$ values obtained in all the analyzed samples, confirming the small spread of the obtained values (mainly between cycles 18 and 20) and the clarity of the products.

Table 1. Tm and Ct of 237/04, 72V/2003, and Hartmannsdorf viruses in infected livers, detected by real-time PCR.

\begin{tabular}{|c|c|c|c|c|}
\hline Strain & Sample Number & Result & $\operatorname{Tm}\left({ }^{\circ} \mathrm{C}\right)$ & $\mathrm{Ct}$ \\
\hline \multirow{6}{*}{$237 / 04$} & 1 & + & 87.51 & 24.57 \\
\hline & 2 & + & 87.52 & 19.78 \\
\hline & 3 & + & 87.55 & 19.95 \\
\hline & 4 & + & 87.56 & 18.05 \\
\hline & 5 & + & 87.60 & 18.78 \\
\hline & 6 & + & 87.59 & 19.00 \\
\hline \multirow{6}{*}{$72 V / 2003$} & 1 & + & 87.32 & 19.04 \\
\hline & 2 & + & 87.42 & 18.06 \\
\hline & 3 & + & 87.38 & 19.71 \\
\hline & 4 & + & 87.63 & 16.68 \\
\hline & 5 & + & 87.47 & 17.59 \\
\hline & 6 & + & 87.38 & 17.74 \\
\hline \multirow{6}{*}{ Hartmannsdorf } & 1 & + & 87.35 & 22.54 \\
\hline & 2 & + & 87.54 & 19.85 \\
\hline & 3 & + & 87.63 & 21.38 \\
\hline & 4 & + & 87.48 & 18.27 \\
\hline & 5 & + & 87.43 & 18.63 \\
\hline & 6 & + & 87.72 & 19.52 \\
\hline
\end{tabular}

Legend: Tm: melting temperature, Ct: cycle threshold. 


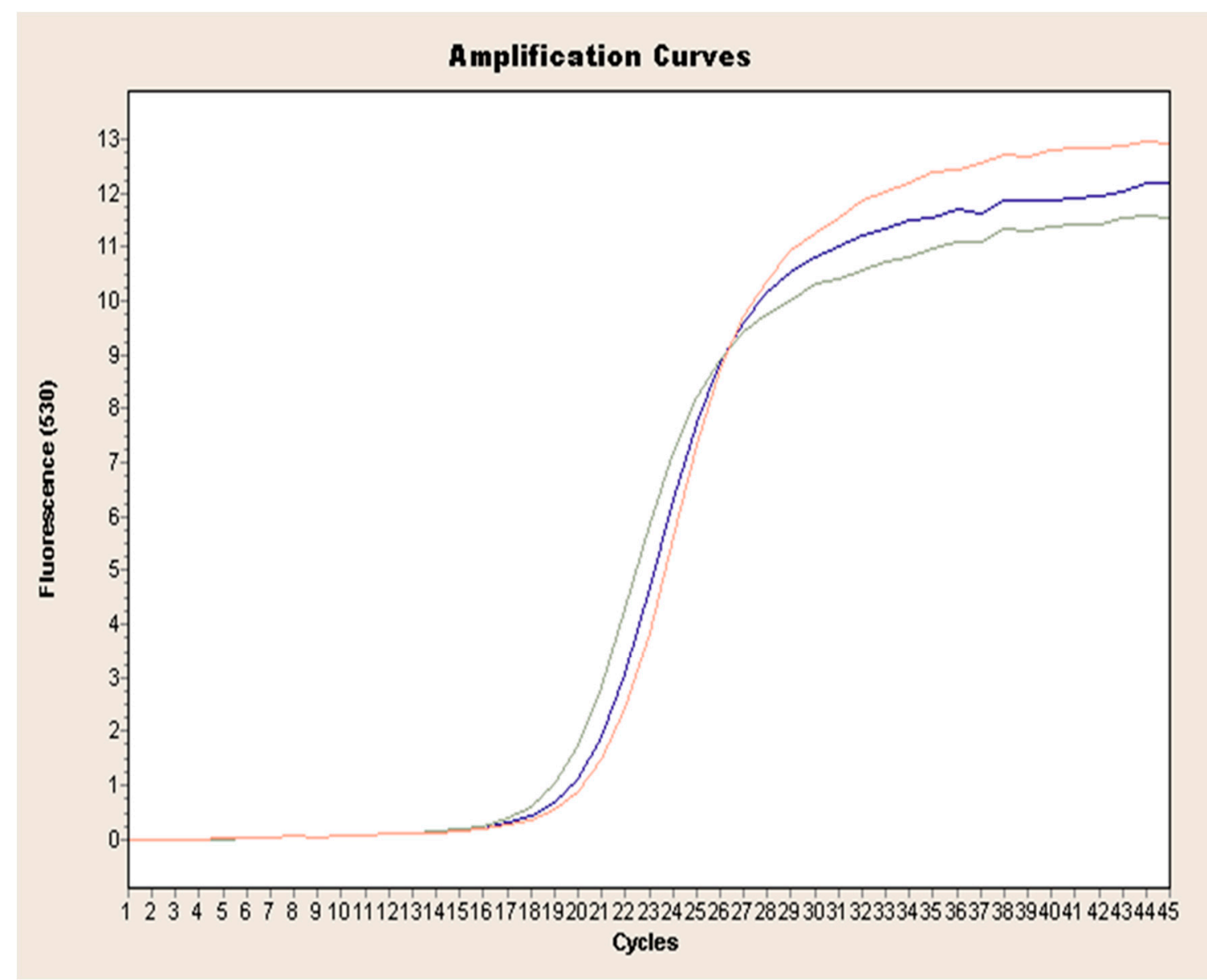

Figure 1. Exemplary amplification curve of real-time PCR obtained for L. europaeus GI.1 on the example of strain $72 \mathrm{~V} / 2003$ (red curve: sample 1, blue curve: sample 2, green curve: sample 3.).

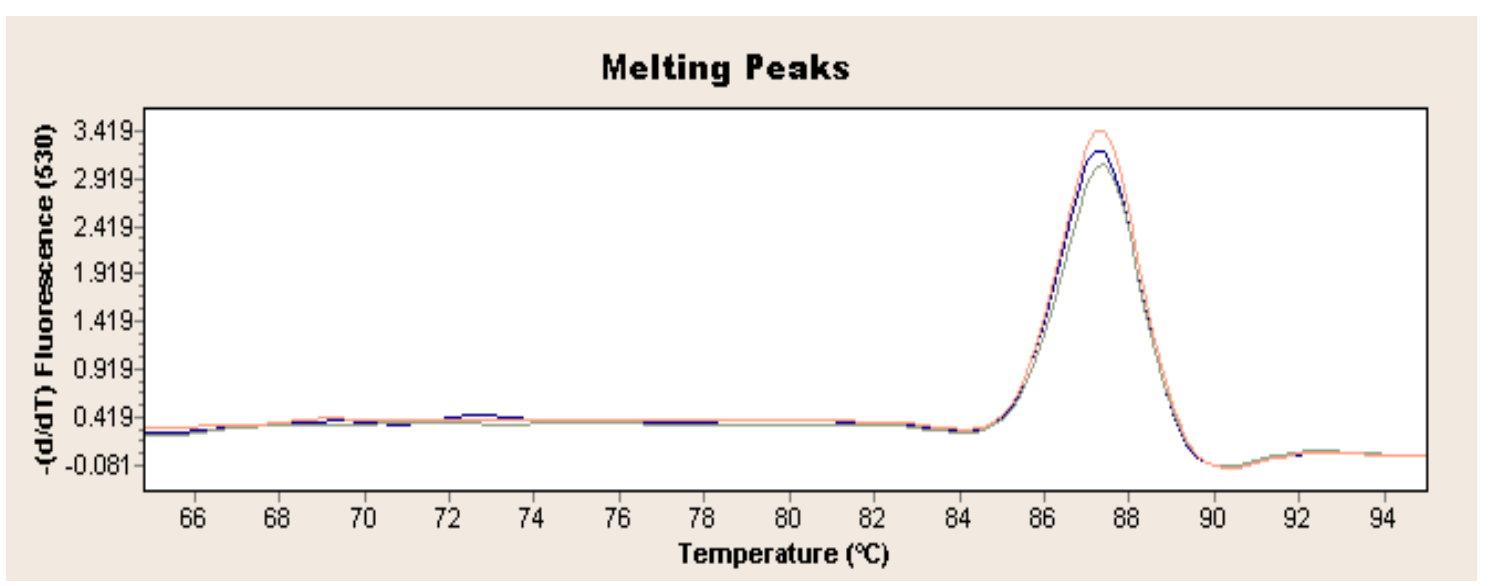

Figure 2. Exemplary result of real-time PCR obtained for L. europaeus GI.1 on the example of strain 72V/2003 (red curve: sample 1, blue curve: sample 2, green curve: sample 3). 


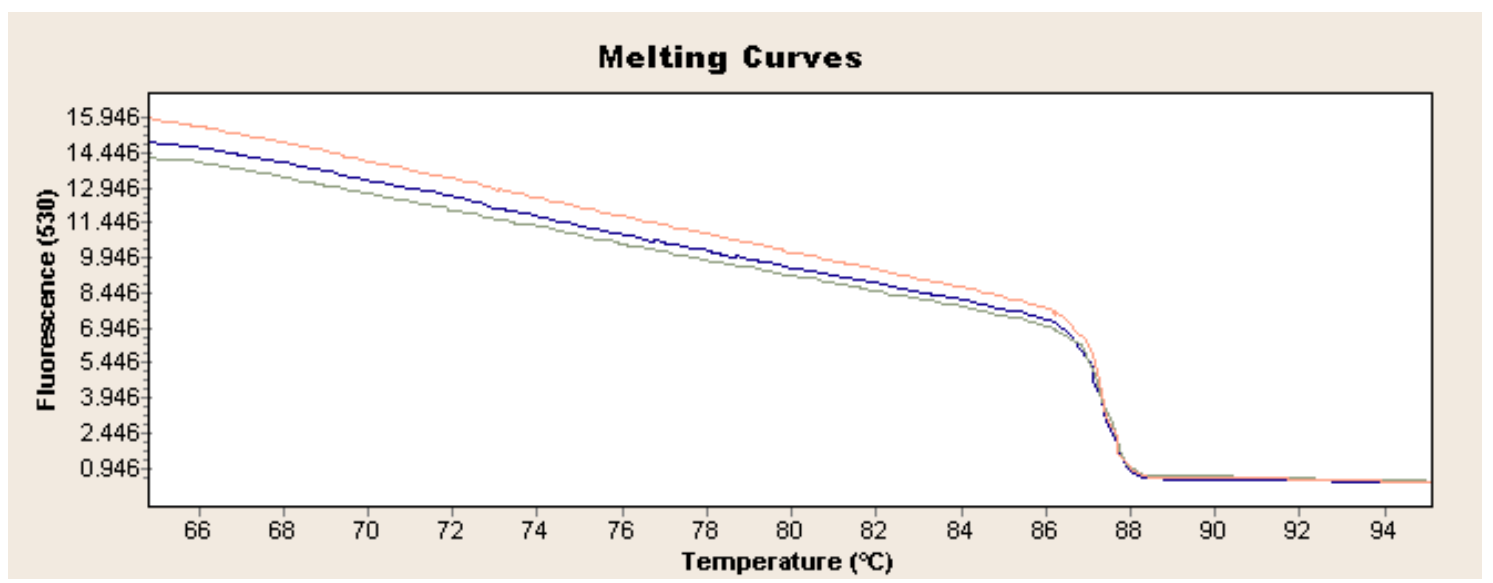

Figure 3. Exemplary analysis of melting curves and temperature for L. europaeus GI.1 on the example of strain $72 \mathrm{~V} / 2003$ (red curve: sample 1, blue curve: sample 2, green curve: sample 3).

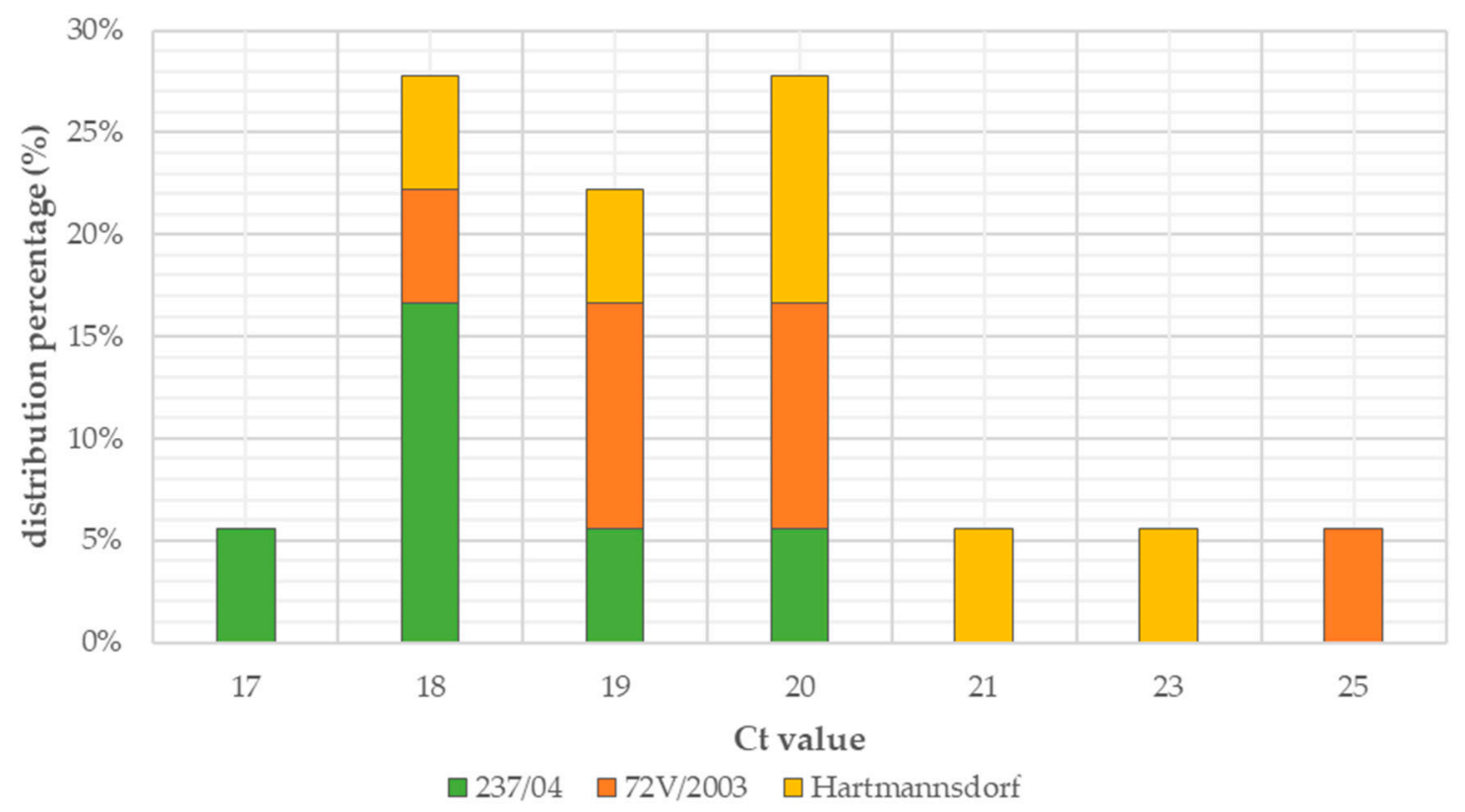

Figure 4. Percentage distribution of Ct values.

\section{Discussion}

The real-time PCR method is a technique that successfully replaces classic PCR in virological research. Due to its high efficiency and the possibility of quantifying a small number of viral particles, it is widely used in research on L. europaeus, including its diagnostics [25]. The list of primers used in published analyses using the real-time PCR method is presented in Table 2. 
Table 2. Characterization of primers used in real-time PCR in L. europaeus GI.1 and GI.2 studies.

\begin{tabular}{|c|c|c|}
\hline Primer & Genogroup & Reference \\
\hline $\begin{array}{c}\text { vp60-7_for-ACYTGACTGAACTYATTGACG } \\
\text { vp60-8_rev-TCAGACATAAGAAAAGCCATT GG }\end{array}$ & \multirow{15}{*}{ GI.1 } & [13] \\
\hline $\begin{array}{l}\text { RHDV-P33(F)-CCACCACCAACACTTCAGGT } \\
\text { RHDV-P34(R)-CAGGTTGAACACGAGTGTGC }\end{array}$ & & [26] \\
\hline $\begin{array}{l}\text { RHDV-RT2-fw-ACCCAGTACGGCACRGGCTCCCAACCAC } \\
\text { RHDV-RT2-rv-CTATCTCCATGAAACCAGATGCAAAGG }\end{array}$ & & [27] \\
\hline $\begin{array}{l}\text { forward primer-TCTGTCGTCAGGCGCACC } \\
\text { reverse primer-GACGAGTAGTTGTTGAGCGAAAG }\end{array}$ & & [14] \\
\hline $\begin{array}{l}\text { forward primer-ACYTGACTGAACTYATTGACG } \\
\text { reverse primer-TCAGACATAAGAAAAGCCATTGG }\end{array}$ & & [4] \\
\hline $\begin{array}{l}\text { forward primer-ACCCAGTACGGCACRGGCTCCCAACCAC } \\
\text { revers primer-CTATCTCCATGAAACCAGATGCAAAGG }\end{array}$ & & \multirow{3}{*}{ [28] } \\
\hline $\begin{array}{l}\text { forward primer-GTTGTATTCGGGCAACCGGAAG } \\
\text { revers primer-CTATGGAACACAAGCAAACATCACCA }\end{array}$ & & \\
\hline $\begin{array}{l}\text { forward primer-GGTTGTTTATGGTGCCTGTAA } \\
\text { revers primer-GCACAAATTACCTTGTCCCAAAAGTTT }\end{array}$ & & \\
\hline $\begin{array}{l}\text { forward primer-ACCCAGTACGGCACRGGCTCCCAACCAC } \\
\text { reverse primer-CTATCTCCATGAAACCAGATGCAAAGG }\end{array}$ & & [29] \\
\hline $\begin{array}{l}\text { VP60-D-Is-GTTCCCACACTGGTCCTTAG } \\
\text { VP60-D-Ia-GTGAGGACTGGGGTCGTGAG }\end{array}$ & & [15] \\
\hline $\begin{array}{l}\text { GI_qRTPCR_Fw-TTGACRTACGCCCTGTGGGACC } \\
\text { GI_qRTPCR_Rv-TCAGACATAAGARAAGCCATTRGYTG }\end{array}$ & & \multirow{4}{*}{ [16] } \\
\hline $\begin{array}{l}\text { GI.1a-Aus_fwd-GCGTGGCATTGTGCGCAGCATCGI.1a-Aus_rev- } \\
\text { TGTTGGTGATAAGCCATAATCGCG }\end{array}$ & & \\
\hline $\begin{array}{l}\text { GI.1c_fwd-AGCAAGACTGTTGACTCAATTTCG } \\
\text { GI.1c_rev-AGGCCTGCACAGTCGTAACGTT }\end{array}$ & & \\
\hline $\begin{array}{l}\text { GI.1a-K5_fwd-TTTATAGATGTATGCCCGCTCAAC } \\
\text { GI.1a-K5_rev-CCGTTCGAGTTCCTTGCGGACG }\end{array}$ & & \\
\hline $\begin{array}{l}\text { RHDVXa2010-F1-GCACCCGGCAGTATTCTC } \\
\text { RHDVXa2010-R1-CCCAGCCAGCGTACATCTG }\end{array}$ & & [30] \\
\hline $\begin{array}{l}\text { RHDV2-F-TGGAACTTGGCTTGAGTGTTGA } \\
\text { RHDV2-R-ACAAGCGTGCTTGTGGACGG }\end{array}$ & \multirow{8}{*}{ GI.2 } & [17] \\
\hline $\begin{array}{l}\text { RHDV2.F1—GTCGTCTCGGTAGTACCTG } \\
\text { RHDV2.R1—GTTGCCTGTCGGGTGGTAC }\end{array}$ & & \multirow{4}{*}{ [18] } \\
\hline $\begin{array}{l}\text { RHDV2.F2-ACAATTCCCTCATGTTGTCATTG } \\
\text { RHDV2.R2-GGGTTGTCAGCTGCAGACC }\end{array}$ & & \\
\hline $\begin{array}{l}\text { RHDV2.3F-GCGGTTTGCCGCCATTGAC } \\
\text { RHDV2.3R-GTTAGCTGAACCGGCCTCAG }\end{array}$ & & \\
\hline $\begin{array}{c}\text { RHDV2.4F-CAGCCAAACAGGATTGTCAATG } \\
\text { RHDV2.4R-CCTGCAAGTCCCAATCCAAC }\end{array}$ & & \\
\hline $\begin{array}{l}\text { 27F-CCATGCCAGACTTGCGTCCC } \\
\text { 986R-AACCATCTGGAGCAATTTGGG }\end{array}$ & & \multirow{2}{*}{ [31] } \\
\hline $\begin{array}{c}\text { 717F-CGCAGATCTCCTCACAACCC } \\
\text { RC10R-GCGCCTGCAAGTCCCAATCC }\end{array}$ & & \\
\hline $\begin{array}{l}\text { RHDVbf-GACCACGACAGAGGTAACGC } \\
\text { RHDVbr-TGTCAGCTGCAGACCCG }\end{array}$ & & [32] \\
\hline
\end{tabular}


Table 2. Cont.

\begin{tabular}{|c|c|c|}
\hline Primer & Genogroup & Reference \\
\hline $\begin{array}{l}\text { RHDV2.F1-GTCGTCTCGGTAGTACCTG } \\
\text { RHDV2.R1-GTTGCCTGTCGGGTGGTAC }\end{array}$ & & \multirow{4}{*}{ [33] } \\
\hline $\begin{array}{l}\text { RHDV2.F2-ACAATTCCCTCATGTTGTCATTG } \\
\text { RHDV2.R2-GGGTTGTCAGCTGCAGACC }\end{array}$ & & \\
\hline $\begin{array}{c}\text { RHDV2.3F-GCGGTTTGCCGCCATTGAC } \\
\text { RHDV2.3R-GTTAGCTGAACCGGCCTCAG }\end{array}$ & & \\
\hline $\begin{array}{c}\text { RHDV2.4F-CAGCCAAACAGGATTGTCAATG } \\
\text { RHDV2.4R-CCTGCAAGTCCCAATCCAAC }\end{array}$ & & \\
\hline $\begin{array}{l}\text { forward primer-TCCAGATGGTTTYCCTGACATG } \\
\text { reverse primer-GCGGTAGGGARGGTGYTG }\end{array}$ & & [34] \\
\hline $\begin{array}{c}\text { GI_qRTPCR_Fw-TTGACRTACGCCCTGTGGGACC } \\
\text { GI_qRTPCR_Rv-TCAGACATAAGARAAGCCATTRGYTG }\end{array}$ & GI.1 and GI.2 & [35] \\
\hline
\end{tabular}

One of the first research teams who used real-time PCR in the diagnosis of L. europaeus GI.1 virus was Le Gall et al. [13], who developed a highly specific real-time PCR method. These studies were then based on the analysis of 13 strains responsible for the RHD outbreaks in Germany in 1989-2004. The analysis of the obtained results revealed 100\% sensitivity of the method and the ability to detect as many as 10 copies of the virus per well, as well as linearity in the range of $10^{1}$ to $10^{10}$ copies [13]. In routine diagnostics, real-time PCR was used by Hanan et al. [36] to diagnose the presence of the virus in 19 liver samples collected from rabbits from three Egyptian provinces (Giza, Kalubia, and Kafr-El-Sheikh). The analysis used specific primers developed in 1995 by Vende et al. [26], based on the gene encoding the VP60 protein. The analysis of the results showed that real-time PCR is a highly efficient and effective method for diagnosing L. europaeus GI.1 infections [36]. Fitzner et al. [37] decided to perform a comparative analysis of the results obtained by conventional PCR and real-time PCR in the diagnosis of infection in the livers of rabbits experimentally infected with 26 strains of L. europaeus GI.1. Analysis of the obtained results revealed linearity ranging from $10^{1}$ to $10^{10}$ copies, which was consistent with the expected values. The high efficiency of the technique was confirmed, as well as a high sensitivity, because it was possible to obtain a positive result using a fivefold dilution of the tested material. The potential of real-time PCR was also verified by Niedźwiedzka-Rystwej et al. [4], who in their research determined the specificity of the virus detection in the livers of rabbits experimentally infected with 17 strains of L. europaeus GI.1, showing different biological characteristics such as antigenicity, hemagglutination capacity of the strain, and induced mortality level. In the tests, the result indicating the presence of the virus in the sample was evidenced by the increase in fluorescence generated by the use of SYBRGreen dye, while the specificity of the reaction was confirmed by the analysis of the melting point of the products, which ranged from $87.23{ }^{\circ} \mathrm{C}$ to $87.65{ }^{\circ} \mathrm{C}$. Thus, it was confirmed that real-time PCR is a highly effective method for the assessment of infection caused by L. europaeus GI.1 with different biological properties [4]. Interesting research using real-time PCR was conducted by Matthaei et al. [28], who compared the replication of the virus in young rabbits experimentally infected with two strains (Czech and Korean) which have been recognized as having potential utility in reducing the abundance of Oryctolagus (O). cuniculus in the environment. In the study, real-time PCR analysis was performed using the fluorescent SYBRGreen dye and primers specific for both strains. Thanks to the conducted study, it was possible to determine that the material derived from rabbits infected with the L. europaeus GI.1a strain contained twelve times more virus than in the CAPM V-351 strain [28]. Real-time PCR was also used by Elsworth et al. [29] in studies on the change in the level of virulence (mortality rate, disease duration, number of progeny virions propagated in the host) of four L. europaeus GI.1 isolates circulating in the natural environment in Australia since 2006. In the studies, it was shown that the analyzed 
samples contained at least $2.5 \times 10^{8}$ copies of the virus, which confirms the high sensitivity of the method used [29]. Beneviedes et al. [38] optimized the real-time PCR method in 2015 with the aim of introducing it as a routine diagnostic measure in the Azores. Thus, its repeatability, reproducibility, specificity, and limit of detection were determined. The performed analysis showed that the reaction efficiency was 94.5\% [38]. Real-time PCR was also used by Liu et al. [15], who analyzed the distribution of viral particles of the XA/2010 L. europaeus GI.1 strain in various parts of the organism in infected rabbits. The analysis revealed that the spleen contained the largest amounts of the virus, while the smallest amounts were found in the contents of the small intestine [15].

The appearance of L. europaeus GI.2 in 2010 was associated with the need to develop a quick and effective diagnostic method. The identification of this factor has proved to be a key tool to limit the emerging epizootics, due to the ineffectiveness of the commonly used vaccines against the GI.1 group. Thus, Duarte et al. [17] proposed the use of real-time PCR, which enables the detection of L. europaeus GI.2 strains in less than three hours. The analysis showed that the applied real-time PCR is a highly specific and sensitive diagnostic method, as only nine viral RNA particles were detected, and the average viral load was $1.5 \times 10^{7}$ virus copies in $1 \mathrm{mg}$ of tissue [17]. The application of this method allowed for the diagnosis of L. europaeus GI.2 infection among dead rabbits found on the islands of Garciosa, Flores, São Jorge, and Terceir. The conducted tests of samples taken from the livers and lungs showed an increased viral load, which amounted to $1.5 \times 10^{8}$ in $1 \mathrm{mg}$ of tissue, but this was explained by an error resulting from the dehydration of the corpses or the age of the examined individuals [39]. Real-time PCR was used by Neimanis et al. [18], thanks to which the presence of L. europaeus GI.2 virus was confirmed in Sweden. The obtained results were also used for the phylogenetic analysis of L. europaeus GI.2, and it was possible to state that despite the presence of the virus in 2016, it had already been circulating in the environment in 2013, but its identification had not been possible without the use of molecular methods [18]. Epidemiological research on RHD is an important point in monitoring the current situation. Calvete et al. [19] carried out studies using real-time PCR, which showed the presence of the virus in the found carcasses of Mediterranean voles (Microtus duodecimcostatus) and in two specimens of shrews (Crocidura russula). Thus, it has been shown that within L. europaeus GI.2, there can be passive transmission of the virus to species beyond the Lagomorph order [19]. The appearance of the L. europaeus GI.2 virus caused a great deal of confusion in many countries, making it necessary to monitor the evolution and spread of this pathogen in wild populations. For this reason, Camacho-Sillero et al. [34] conducted an analysis to assess the picture of the RHD epidemic caused by GI.2 strains in southern Spain in 2013-2017. The analysis of the obtained results showed that the GI.2 strains predominate in the study area, which in turn confirms the usefulness and efficiency of the real-time PCR method in epidemiological analyses [34].

The wide application possibilities of real-time PCR in multidirectional research on L. europaeus GI.1 and GI.2 certainly confirm the advantages of this method. Nevertheless, it has serious limitations. A definite disadvantage of this method is the use of expensive specialized equipment, without which it is impossible to carry out the reaction. The preparation of the sample itself can be tedious as well. Moreover, in real-time PCR, PCR product increases exponentially and variation increases with cycle number [40]. In some cases, overlapping of the emission spectra can be observed, causing an increased risk of false negative results [40]. Currently, more methods are available that allow for the rapid diagnosis of pathogen infection, such as reverse transcription loop-mediated isothermal amplification (RT-LAMP) and clustered regularly-interspaced short palindromic repeats (CRISPR) [41], so you should consider limiting the use of real-time PCR for other analyses not necessarily aimed at diagnostics. Real-time PCR is a very sensitive diagnostic method and therefore false-positive results may be obtained when testing vaccinated rabbits. Calvarho et al. [31] conducted an experiment in which they detected RNA from vaccines using real-time PCR. The obtained results revealed that RNA vaccine becomes undetectable 15 days after inoculation, which is a very important aspect when interpreting the results of 
diagnostic analyses. Simultaneous occurrence of various L. europaeus viruses, including group GI.2, as well as their recombinants, is observed in many places. Pay special attention to the current epidemiological situation to avoid false results due to primers of inadequate specificity. For this reason, Dalton et al. [32] developed a real-time PCR method for effective diagnostics of all circulating lagoviruses. In order to design primers, 66 partial sequences of the L. europaeus GI.2 VP60 protein were compared, which were obtained from the GenBank database. In Australia, L. europaeus GI.1 is a widely used biological control agent for the European rabbit population, which in this area is considered a pest that adversely affects both the environment and agriculture. So far, it has been found that four different lagoviruses circulate in Australia, three of which belong to the GI.1 group: CAPM V-351, GI.1a-K5, and GI.1a-Aus. Thus, there was a need to develop a test that detects all these factors, which is why Hall et al. [16] described a specific real-time PCR test to differentiate the circulating strains. Specific primers dedicated to individual viruses were developed using the sequences encoding the VP60 and RdRp genes [16].

\section{Conclusions}

In our research we confirmed the effectiveness of real-time PCR in the analysis of L. europaeus GI.1. Real-time PCR is a very attractive method that can be used not only for a quick diagnosis of a disease factor, but also in the entire spectrum of tests, the effects of which allow us to learn about previously unknown aspects of infection, as well as prevention and applied therapeutic measures. However, note that this method also has limitations. Very high sensitivity of the reaction can cause false results, therefore real-time PCR requires careful optimization of the reaction and people who interpret the results must demonstrate great experience. Moreover, in the studies of L. europaeus GI.1 and GI.2, particular attention should be paid to the selection of appropriate primers, depending on the expected results. The use of non-specific primers can also affect the false results of analyses.

Author Contributions: Conceptualization, P.N.-R.; methodology, P.N.-R., D.B., and R.H.; software, D.B. and R.H.; validation, D.B., R.H., and P.N.-R.; formal analysis, P.N.-R.; investigation, D.B. and R.H.; resources, P.N.-R.; data curation, D.B., R.H., and P.N.-R.; writing—original draft preparation, D.B.; writing - review and editing, D.B., R.H., and P.N.-R.; visualization, D.B. and R.H.; supervision, P.N.-R.; project administration, P.N.-R.; funding acquisition, P.N.-R. All authors have read and agreed to the published version of the manuscript.

Funding: This research received no external funding.

Institutional Review Board Statement: The study was conducted according to the guidelines of the Declaration of Helsinki, and approved by the Local Ethics Committee for Experiments on Animals in Poznań (license no. 1/2009).

Informed Consent Statement: Not applicable.

Data Availability Statement: Data sharing not applicable.

Conflicts of Interest: The authors declare no conflict of interest.

\section{References}

1. Abrantes, J.; van der Loo, W.; Le Pendu, J.; Esteves, P.J. Rabbit haemorrhagic disease (RHD) and rabbit haemorrhagic disease virus (RHDV): A review. Vet. Res. 2012, 10, 12. [CrossRef] [PubMed]

2. Bębnowska, D.; Niedźwiedzka-Rystwej, P. Characteristics of a new variant of rabbit haemorrhagic disease virus-RHDV2. Acta Biol. 2019, 15, 83-97. [CrossRef]

3. Abrantes, J.; Lopes, A.M.; Dalton, K.P.; Parra, F.F.; Esteves, P.J. Detection of RHDVa on the Iberian Peninsula: Isolation on an RHDVa strain from a Spanisch rabbitry. Arch. Virol. 2014, 159, 321-326. [CrossRef] [PubMed]

4. Niedźwiedzka-Rystwej, P.; Hukowska-Szematowicz, B.; Działo, J.; Tokarz-Deptuła, B.; Deptuła, W. Real time PCR detection of rabbit haemorrhagic disease virus in $\mathrm{r}$ abbits infected with different Euripean strains of RHDV. Pol. J. Vet. Sci. 2013, 16, 39-43. [CrossRef]

5. International Committee on Taxonomy of Viruses (ICTV). Available online: https://talk.ictvonline.org/ictv-reports/ictv_online_ report/positive-sense-rnaviruses/w/caliciviridae/1163/genus-lagovirus/ (accessed on 22 July 2020). 
6. Le Pendu, J.; Abrantes, J.; Bertagnoli, S.; Guitton, J.S.; Le Gall-Reculé, G.; Lopes, A.M.; Marchandeau, S.; Alda, F.; Almeida, T.; Célio, A.P.; et al. Proposal for a unified classification system and nomenclature of lagoviruses. J. Gen. Virol. 2017, 98, 1658-1666. [CrossRef]

7. Liu, S.J.; Xue, H.P.; Pu, B.Q.; Quian, N.H. A new viral disease in rabbits. Anim. Hus. Vet. Med. 1984, 16, $253-255$.

8. Capucci, L.; Fallacara, F.; Grazioli, S.; Lavazza, A.; Pacciarini, M.L.; Brocchi, E. A further step in the evolution of rabbit hemorrhagic disease virus: The appearance of the first consistent antigenic variant. Virus Res. 1998, 58, 115-126. [CrossRef]

9. Oem, J.K.; Lee, K.N.; Roh, I.S.; Lee, K.K.; Kim, S.H.; Kim, H.R.; Park, C.K.; Joo, Y.S. Identification and Characterization of Rabbit Hemorrhagic Disease Virus Genetic Variants Isolated in Korea. J. Vet. Med. Sci. 2009, 71, 1519-1523. [CrossRef]

10. Le Gall-Recule, G.; Zwingelstein, F. Detection of a new variant of rabbit haemorrhagic disease virus in France. Vet. Rec. 2011, 168, 137-138. [CrossRef]

11. Burmakina, G.; Malogolovkina, N.; Lunitsin, A.; Titov, I.; Tsybanov, S.; Malogolovkin, A. Comparative analysis of rabbit haemorrhagic disease virus strains originating from outbreaks in the Russian Federation. Arch. Virol. 2016, 16, 1973-1979. [CrossRef]

12. Song, Y.; Wang, F.; Fan, Z.; Hu, B.; Liu, X.; Wei, H.; Xue, J.; Xu, W.; Qiu, R. Identification of novel rabbit hemorrhagic disease virus B-cell epitopes and their interaction with host histo-blood group antigens. J. Gen. Virol. 2016, 97, 356-365. [CrossRef] [PubMed]

13. Gall, A.; Hoffmann, B.; Teifke, J.P.; Lange, B.; Schirrmeier, H. Persistence of viral RNA in rabbits which overcome an experimental RHDV infection detected by a highly sensitive multiplex real-time RT-PCR. Vet. Microbiol. 2007, 120, 17-32. [CrossRef] [PubMed]

14. Nyström, K.; Le Gall-Reculé, G.; Grassi, P.; Abrantes, J.; Ruvoën-Clouet, N.; Le Moullac-Vaidye, B.; Lopes, A.M.; Esteves, P.J.; Strive, T.; Marchandeau, S.; et al. Histo-blood group antigens act as attachment factors of rabbit hemorrhagic disease virus infection in a virus strain-dependent manner. PLoS Pathog. 2011, 7, e1002188. [CrossRef] [PubMed]

15. Liu, W.; Dand, R.; Wang, X. Development of a SYBR-based real-time PCR to detect rabbit hemorrhagic disease virus (RHDV) and analyze its tissue distribution in experimentally infected rabbits. Virol. Sin. 2015, 30, 228-230. [CrossRef] [PubMed]

16. Hall, R.N.; Mahar, J.E.; Read, A.J.; Mourant, R.; Piper, M.; Huang, N.; Strive, T. A strain-specific multiplex RT-PCR for Australian rabbit haemorrhagic disease viruses uncovers a new recombinant virus variant in rabbits and hares. Transbound. Emerg. Dis. 2018, 65, e444-e456. [CrossRef] [PubMed]

17. Duarte, M.D.; Carvalho, C.L.; Barros, S.C.; Henriques, A.M.; Ramos, F.; Fagulha, T.; Luis, T.; Duarte, E.L.; Fevereiro, M. A real time Taqman RT-PCR for the detection of rabbit hemorrhagic disease virus 2 (RHDV2). J. Virol. Methods 2015, 219, 90-95. [CrossRef]

18. Neimanis, A.S.; Ahola, H.; Zohari, S.; Larsson Pettersson, U.; Bröjer, C.; Capucci, L.; Gavier-Widén, D. Arrival of rabbit haemorrhagic disease virus 2 to northern Europe: Emergence and outbreaks in wild and domestic rabbits (Oryctolagus cuniculus) in Sweden. Transbound. Emerg. Dis. 2018, 65, 213-220. [CrossRef]

19. Calvete, C.; Mendoza, M.; Sarto, M.P.; Bagues, M.P.J.; Lujan, L.; Molin, J.; Calvo, A.J.; Monroy, F.; Calvo, J.H. Detection of Rabbit Hemorrhagic Disease Virus GI.2/RHDV2/b in the Mediterranean Pine Vole (Microtus duodecimcostatus) and White-Toothed Shrew (Crocidura russula). J. Wildl. Dis. 2019, 55, 467-472. [CrossRef]

20. Niedźwiedzka-Rystwej, P.; Tokarz-Deptuła, B.; Hukowska-Szematowicz, B.; Działo, J.; Deptuła, W. Indices of non-specific immunity-An element of natural immunity in rabbits infected with RHD (rabbit haemorrhagic disease) virus. Centr. Eur. J. Immunol. 2013, 38, 232-236. [CrossRef]

21. Niedźwiedzka-Rystwej, P.; Tokarz-Deptuła, B.; Hukowska-Szematowicz, B.; Działo, J.; Trzeciak-Ryczek, A.; Deptuła, W. Peripheral blood lymphocytes $\mathrm{B}$ and $\mathrm{T}$ and their subpopulations in rabbit infected with rabbit haemorrhagic disease virus (RHDV). Med. Wet. 2013, 59, 484-487.

22. Niedźwiedzka-Rystwej, P.; Hukowska-Szematowicz, B.; Tokarz-Deptuła, B.; Trzeciak-Ryczek, A.; Działo, J.; Deptuła, W. Apoptosis of peripheral blood leucocytes in rabbits infected with different strains of rabbit haemorrhagic disease virus. Acta Biochem. Pol. 2013, 60, 65-69. [CrossRef]

23. Niedźwiedzka-Rystwej, P.; Deptuła, W. Lymphocyte subpopulations and apoptosis of immune cells in rabbits experimentally infected with a strain of the RHD virus having a variable haemagglutination capacity. Pol. J. Vet. Sci. 2012, 15, 43-49. [CrossRef] [PubMed]

24. Adamiak, M.; Niedźwiedzka-Rystwej, P.; Tokarz-Deptuła, B. Presence of the RHD (Rabbit haemorrhagic disease) virus in liver cells of rabbits determined by real-time PCR method. PhD Int. J. 2013, 1, 9-12.

25. Kwit, E.; Rzeżutka, A. Molecular methods in detection and epidemiologic studies of rabbit and hare viruses: A review. J. Vet. Diagn. Invest. 2019, 31, 497-505. [CrossRef]

26. Vende, P.; Le Gall, G.; Rasschaert, D. An alternative method for direct sequencing of PCR products for epidemiological studies performer by nucleic sequence comparison. Application of rabbit haemorrhagic disease virus. Vet. Res. 1997, 26, 174-179.

27. Strive, T.; Wright, J.; Kovaliski, J.; Botti, G.; Capucci, L. The non-pathogenic Australian lagovirus RCV-A1 causes a prolonged infection and elicits partial cross-protection to rabbit haemorrhagic disease virus. Virology 2010, 398, 125-134. [CrossRef]

28. Matthaei, M.; Kerr, P.J.; Read, A.J.; Hick, P.; Haboury, S.; Wright, J.D.; Strive, T. Comparative quantitative monitoring of rabbit haemorrhagic disease viruses in rabbit kittens. Virol. J. 2014, 11, 109. [CrossRef]

29. Elsworth, P.; Cooke, B.D.; Kovaliski, J.; Sinclair, R.; Holmes, E.C.; Strive, T. Increased virulence of rabbit haemorrhagic disease virus associated with genetic resistance in wild Australian rabbits (Oryctolagus cuniculus). Virology 2014, 464-465, 415-423. [CrossRef] 
30. Mahar, J.E.; Read, A.J.; Gu, X.; Urakova, N.; Mourant, R.; Piper, M.; Habaury, S.; Holmes, E.C.; Strive, T.; Hall, R.N. Detection and Circulation of a Novel Rabbit Hemorrhagic Disease Virus in Australia. Emerg. Infect. Dis. 2018, 24, 22-31. [CrossRef]

31. Carvalho, C.L.; Duarte, E.L.; Monteiro, M.; Botelho, A.; Albuquerque, T.; Fevereiro, M.; Henriques, A.M.; Barros, S.S.; Duarte, M.D. Challenges in the rabbit haemorrhagic disease 2 (RHDV2) molecular diagnosis of vaccinated rabbits. Vet. Microbiol. 2017, 198, 43-50. [CrossRef]

32. Dalton, K.P.; Arnal, J.L.; Benito, A.A.; Chacon, G.; Martin Alonso, J.M.; Parra, F. Conventional and real time RT-PCR assays for the detection and differentiation of variant rabbit hemorrhagic disease virus (RHDVb) and its recombinants. J. Virol. Methods 2018, 251, 118-122. [CrossRef] [PubMed]

33. Neimanis, A.S.; Ahola, H.; Larsson Pettersson, U.; Lopes, A.M.; Abrantes, J.; Zohari, S.; Estaves, P.J.; Gavier-Widen, D. Overcoming species barriers: An outbreak of Lagovirus europaeus GI.2/RHDV2 in an isolated population of mountain hares (Lepus timidus). BMC Vet. Res. 2018, 14, 367. [CrossRef]

34. Camacho-Sillero, L.; Caballero-Gomez, J.; Gomez-Guillamon, F.; Martinez-Padilla, A.; Aguero, M.; San Miquel, E.; Zorrilla, I.; Rayas, E.; Talavera, V.; Garcia- Bocanegra, I. Monitoring of the novel rabbit haemorrhagic disease virus type 2 GI2 epidemic in European wild rabbits (Oryctolagus cuniculus) in southern Spain, 2013-2017. Veter. Micriobiol. 2019, 237, 108361. [CrossRef] [PubMed]

35. Naeve, M.J.; Hall, R.N.; Huang, N.; McColl, K.A.; Kerr, P.; Hoehn, M.; Strive, T. Robust Innate Immunity of Young Rabbits Mediates Resistance to Rabbit Hemorrhagic Disease Caused by Lagovirus Europaeus GI.1 But Not GI.2. Viruses 2018, 10 , E512. [CrossRef]

36. Hanan, A.F.; Arafa, A.; Mahamoud, A.H. Molecular diagnosis of rabbit hemorrhagic disease virus (RHDV). Egypt J. Comp. Path Clinic. Path. 2010, 23, 85-101.

37. Fitzner, A.; Niedbalski, W.; Kęsy, A.; Paprocka, G. Detection of RHD virus by Real-time Reverse Transcription PCR. Bull. Vet. Inst. Pulawy 2011, 55, 581-586.

38. Beneviedes, S.; Toste, S.; Bernando, S.A.; Flor, L. Optimization of a real time PCR for the detection of rabbit haemorrhagic disease virus in infected rabbits from Azores. RPCV 2015, 110, 593-594.

39. Duarte, M.; Carvalho, C.; Bernardo, S.; Barros, S.V.; Benevides, S.; Flor, L.; Monteiro, M.; Marques, I.; Henriques, M.; Barros, S.C.; et al. Rabbit haemorrhagic disease virus 2 (RHDV2) outbreak in Azores: Disclosure of common genetic markers and phylogenetic segregation within the European strains. Infect. Genet. Evol. 2015, 35, 163-171. [CrossRef]

40. Klein, D. Quantification using real-time PCR technology: Applications and limitations. Trends Mol. Med. 2002, 8, 257-260. [CrossRef]

41. Jayamohan, H.; Lambert, C.J.; Sant, H.J.; Jafek, A.; Patel, D.; Feng, H.; Beeman, M.; Mahmood, T.; Nze, U.; Gale, B.K. SARSCoV-2 pandemic: A review of molecular diagnostic tools including sample collection and commercial response with associated advantages and limitations. Anal. Bioanal. Chem. 2020, 1-23. [CrossRef] 